\title{
ON-LINE / INTERNET COMMENTS AS THE REFLECTION OF NATIONAL MENTALITY \\ (CASE STUDY OF THE FRENCH AND RUSSIAN LANGUAGES)
}

\author{
Anastasia Vladimirovna Ageeva \\ Kazan Federal University, Kazan, Russian Federation \\ Liliya Rafailovna Abdullina \\ Kazan Federal University, Kazan, Russian Federation \\ Nyaz Rastamovich Latypov \\ Kazan Federal University, Kazan, Russian Federation
}

\begin{abstract}
The article deals with with revealing of the features of language representation of a national worldview of the Frenchmen in comments to political news seen as a genre of virtual discourse. The analysis of the the problem of transforming the genre of comment due to the peculiarities of the Internet communication initiated in the different recent studies and based on the modern demands of the virtual discourse questions the traditional interpretation of different languages genres and their peculiarities. Not only the journalists and the experts, but the readers as well are considered to be the subjects of communication. The research on of comments establishes the communicative intentions of addressers and the ways of their realization. The study of the specic frames verbalized in the statements in communicative intention shows the importance of the frame structure of comments for reflection of a national worldview of the communicants. The analysis defines the role of the language person in the type of discourse under study, justifies the possibility of reconstructing the national worldview based on numerous on-line comments to the articles related to news, which attract the greatest attention and feedback of the readers.
\end{abstract}

Keywords: internet comments, national mentality, virtual discourse, national identity, perception of the world, frame, subframe, slot.

\section{INTRODUCTION}

Over the last decades, the linguists focus on the linguistic features of different genres of online discourse, dominated by chats, forums, and blogs. There is a growing number of research papers dedicated to the analysis of online comments gaining popularity in the news feeds of different websites. This fact is confirmed by the dynamics of this genre study: if first papers representing case study of online comments analyze only the problem of negative apprasive modality and epistemic speech acts $[1 ; 2]$, then all the works that followed were dedicated to the substantiation of Internet comments being treated and approached as a separate speech genre of online discourse $[3 ; 4 ; 5 ; 6 ; 7,8]$. there are primarily linguocultural features of national linguistic identity $[9 ; 10 ; 11]$ and communicative means of influence $[12 ; 13 ; 14]$ in the limelight of scientific research. This research attempts comparative analysis of internet comments in multistructural languages in the context of pragmasemantic paradigm. The main purpose of the study is to identify national cultural specificity of perception of the described events represented by means of linguistic tools in online comments. As for the research hypothesis we build our study on the assumption that the online comments could represent national features specific to culture and history of the people speaking the language under study and determined by their habitat.

\section{MATERIALS AND METHODS}

To achieve this objective the research is based on such methods as comparative contrastive, statistical methods and the method of frame modeling. 
Overall scope of allomorphic and isomorphic properties of the studied languages is elaborated through interlingual comparison. Linguistic features comparison allows for more profound representation of originality of the compared phenomena.

The study applies linguistic statistic method in order to interpret the emergence of various elements in speech since the latter is affected not only by the language norms and principles, but is influenced by genre specificities and topics of utterance.

Frame modeling method allows for categorizing contextual frames that comprise the core of the frame structure of the utterance within which subframes could be identified. Subframes are the levels constituting a set of thematically universal features and representing a sequence of hierarchally structured slots $[11,91 ; 15$, 145].

Online comments to the articles found on the leading news websites of French (Lemonde.fr, Liberation.fr) and Russian (ria.ru, gazeta.ru, lenta.ru) languages served as study material.

\section{RESULTS}

The major difference is manifested in the number of comments that vary depending on the topic of the discussion. So, if the latter has political or economical background, the highest response among the readers will be produced by the articles directly relevant to their country. For example, news about the anti-crisis plan to be promulgated by the Government of the Russian Federation was followed by more than 500 comments several hours after it was published (Lenta.ru dated 01.28.2015). The leading French periodicals did not have any references to that news, because it does not affect the national interests of France and the European Union it is a member of.

Another international example should be analyzed for comparison. It is an open secret that any reference to Russia made in foreign media last year is related to Ukraine, with notably negative connotation. Therefore the news dated 25.01.2015 about strategic port of Mariupol in the eastern part of Ukraine being attacked was cited by all foreign mass media agencies and caused a stormy stir among the readership: 144 comments on Lemonde.fr website, 291 comments on liberation.fr with arduous reference to Russia. The number of the comments on that news in the Russian media outlets amounts to 359 on Lenta.ru

The major difference between comments is that Russian media is dominated by positive references to our country while overseas agencies provide negative comments on Russia. Accordingly, fact-based objective analysis of online comments in both languages requires to disregard news and comments related to Ukraine and focus on news about the expansion of circulation of the satirical periodical Charlie famous for its controversial caricatures, particularly for publishing caricatures of Prophet Mohamed, which sparked tremendous public outcry: that event is not a means of some kind of propaganda or manipulative impact made on nation neither by the government nor by any media agency. There were analyzed 108 comments in every language taken from the abovementioned Russian and French websites.

In the first stage of the study we focus on comments' referent that could be:

1. The characters of the commented article (in our case it is "Charlie Hebdo" periodical) and all the events related to them (number of copies printed amounted to $7 \mathrm{mln}$.). This is about the key issues covered by the author of the article. For example:

In the French language: Les speculateurs/profiteurs qui ont acheté $\mathrm{CH}$ par paquets de 10 en espérant en retirer un profit en seront pour leurs frais !

In the Russian language: «Тираж Charlie увеличен до 7 млн.», - а что у них кроме Пророка не было других карикатурных объектов.

It is worth mentioning that number of French comments relevant to the topic of the article reaches $81 \%$, while in Russian it totals at 50\%. The reason of the French people's interest to the article referent could be explained by the fact that the issues dwelled on in it are important and relevant for the nation and the country at large. It is quite likely that some of the users who commented personally took part in the public mass 
demonstrations connected with Charlie, thus contributing to growth of that periodical profitability. Whereas Russians observe the events in France remotely not being present on site.

2. Other internet commentators of the article.

There are comments the viewpoint of which is different from the previous left, and often cause verbal aggression. We believe in this case it is appropriate to cite the saying by Steksova T.I. that "those users whose opinion coincides with the opinion of the commentator are treated as their "friends" or "insiders", but those whose opinion is different from the commentator's opinion are clearly perceived as "aliens" and provoke verbal aggression" $[14,78]$. In the latter case, other commentators, losing focus on the article topic, spring on the commentator. Similar examples are also documented in both languages

In the French language: Votre remarque porte sa propre conradiction. Aucune "mère » ou "personne " n'est insultée ici....

In the Russian language: Bиктор, вообще никого не интересует твой долбаный атеизм. Как ты к этому пришел и как ты уйдешь от этого маразма, если вообще уйдешь....

In this regard it stands to mention that the number of such comments in French does not exceed $6 \%$ while in the Russian language it goes up to $14 \%$. This fact proves that Russians have more controversial opinion about the events evolving in France than the French people.

3. Representative of other social groups (of different religious or territorial background, involved in various spheres of social activity) are of peripheral significance in this article. It could be exemplified by the following comments:

In the French language: Les terroristes n'aiment pas notre liberté de ton? Vite, montrons leur qu'ils sont entendus et établissons le délit de blaphème. The article has no reference to terrorists, though they are recalled by the internet commentators.

In the Russian language: Еще краски на карикатурах не успели высохнуть, а транспаранты, осуждающие выходки террористов, уже были готовы...

Similarly the author of the article expresses his personal viewpoint concerning his attitude to French people taken as a whole. Here is another example: Франщия проголосовала за создание палестины, мусульмане растоптали флаг Франции в мечети Аль-Акса!

The author raises here the question of the relationship between the French authorities and the Muslim community, which also has no direct association with the text of the article. It would be more relevant as far as the terrorist attacks on the publishers' office are concerned.

According to the statistics number of such comments equaled to $13 \%$ in the French language and $36 \%$ in Russian correspondingly. Terrorists and Muslims are the core elements in both languages are. In addition, the Russian-language comments also highlight the French themselves as a nation and France as EU member, a part of Europe. For example: Больные люди, однако, эти франиузы... / Как все бездумно, плоско, примитивно и дико! Привет, недоразвитая Европа!

At the second stage of the study we shall focus on the frame analysis of the material closely associated with the referents described above comments. Table 1 represents a frame-based structure of the Internet comments as part of a given situation.

Table 1. Frames verbalized in the French and Russian Internet comments

\begin{tabular}{|l|c|cc|}
\hline \multicolumn{1}{|c|}{ Levels } & French comments & \multicolumn{2}{c|}{ Russian comments } \\
\hline Frame & Charlie Hebdo & \multicolumn{2}{|c|}{ Frenchmen } \\
\hline Subframe & Tirage (slots: Caricature, Victimes, Liberté & Шарли & (slots: Карикатура, Тираж, \\
\hline
\end{tabular}




\begin{tabular}{|l|l|l|}
\hline & $\begin{array}{l}\text { d'expession ) } \\
\text { Terrorisme (slots: Islam, Terroristes) }\end{array}$ & $\begin{array}{l}\text { Журналисты, Европа) } \\
\text { Terrorisme (slots: Ислам, Террористы) }\end{array}$ \\
\hline
\end{tabular}

As the table shows, the initial difference is already apparent at the frame level.

Charlie Hebdo periodical serves as the frame in the French comments, while Russian comments are more focused on the French themselves. Given discrepancy predetermined the different level of frames representation. The notion of "Tirage" is identified as the subframe in the French language, while in the Russian language the latter represents one of the slots of "Charlie" subframe complemented with similar to French slots "Caricature" (Шарли-Мы_эники такие! Последние шттаны снимут, чтобы купить сортирную карикатуру и сдохнуть!/La Caricature ne tue pas...) and «Журналисты / Victimes» (Один вопрос... а кто заказал убийство этих несчастных журналистов, чтобы поднять тираж?/ Les fonds récoltés via cette vente exceptionnelle vont aller en grande partie aux victimes de l'attentat).

"Tirage" subframe is dominated by "Liberté d'expession" slot, as for the Russian comments the topic of freedom of press is dwelled on within the "Charlie" subframe but it represents superordiante concept in realtion to "Europe" slot (В России за это уголовная статья. В аморальной европе... оскорбление верующих это свобода слова).

It should be noted that Russian comments have obvious linguistic harrassment towards the periodical expressed by means of various insulting periphrasis, for instance: редакиия мелкого журнальчика, скотобаза современной журналистики, грязная газетенка. Users giving comments in French generally take neutral stance on the issue avoiding any negative references to the periodocal.

Even such lexical units as "devenu ambassadeur de France mais absolument pas pacificateur", "Journal anarchiste" have no invective connotation, while the semnatics of the Russian words and chunks against the editorship, on the contrary, contain author's intention to humiliate, insult the referent in the most disparaging, disrespectful, rude and cynical manner. Invective expressions are often used towards the French themselves, and Europe as a whole (Лягушатники - идиоты).Obviously, the situation is influenced by rather tense relations with EU due to sanctions imposed on Russia, thus, resulting in cognitive dissonance and condemnation on the part of the Russian readership.

Having regard to the above, the Russians' perception of French caricatures is apparently predetermined by personal experience and inherited from the Soviet times attitude to "inflammatory" content. However, analyzing the history of French caricatures (Hara-Kiri, for example), we will see that similar caricatures of Soviet authorities, Church, that are not considered by the French as provocations and did not lead to murdering the painters. Cultural traditions of France, under influence of which Charlie Hebdo was established and evolved, are explicitly different from the Russian canons. It is commonly known that Russians treat religious caricatures as absolute taboo, which explains the upsurge of indignation provoked by moral crusaders and champions of traditional virtues.

Isomorphism of comments in both languages is manifested in "Terrorism" subframe filled with slots "Islam" (Не прогибаются перед аморальным мракобесием как раз мусульмане.. / Quand les religions font de la politique, et c'est bien le cas de l'Islam radical...) and "Terrorists" (Ничего святого, франиузского издательство наваривается даже на трагедии. При этом провоцирует обложкой исламистов, которых в европейских странах тысячи, на новые террористические атаки. Зачем еще подливать масла в огонь?/ Les terroristes n'aiment pas notre liberté de ton?). Russian government actively promotes global fight against terrorism. In this regard a wave of solidarity with France is quite logical.

Comments may often have some incidental references to other figures misleading the foreign readers at times, because some personalities or events in the country have no mass media coverage in other states and, correspondingly, the readership is not familiar with it. Nevertheless, while analyzing the situation the native speaker may associate the events and interconnect the incidents. Here are some extracts to exemplify and prove out the above-mentioned. 
The Turkish Online Journal of Design, Art and Communication - TOJDAC July 2016 Special Edition

\section{STAEDLER}

Charlie Hebdo est donc le seul journal à publier des caricatures de Mahomet dans le monde... la liberté d'expression est une particularité Française par contre l'affiche de Timsit a été censurée elle...

\section{Drawer 77}

Vous mélangez tout. Charlie Hebdo est un magazine qu'il faut acheter pour voir son contenu. JCDecaux s'occupe de l'affichage sur la voie publique et dans le métro, ce qui est visible par tout le monde.

What do the authors refer their comments to? Major French advertising company JCDecaux censored the billboard of the performance of a famous actor and scriptwriter Patrick Timsit (15.01.2015). "You can not make fun of everything" says the performance poster featuring a laughing actor hugging a bomb. Company refused to advertise the performance alleging as the reason that the given image might hurt the feelings of passers-by after the tragic events. Obviously, the commentator considers the company's decision to be absurd, especially amidst continuous and ubiquitous statements about the freedom of expression. Another conversant responds with disagreement with JCDecaux's decision. It is quite reasonable that these names are not mentioned in the Russian comments. There are more of sarcastic comments against the Ukrainian government: В киеве треба журнал распространять. Добавить карикатуру с яценюком. Поржет военное сообщество, повысится боеготовность...

\section{DISCUSSION}

As the frame analysis of the research material has shown, caricature scandal described in the study failed to foster unity between Russia and Europe, but on the contrary, highlighted the differences between the countries. It is evident from the allomorphic features discovered during the analysis of linguistic material of multistructural languages which emphasize the impact of cultural historical values of different countries on verbal representation of reality based on determining personal priorities by means of hierarchization of images' notions, correlation of previously accumulated experience of a person and his environment with relevant objects of reality, determination of behavior and activity of the subject as a participant of the communicative act.

\section{ACKNOWLEDGEMENTS}

The work is performed according to the Russian Government Program of Competitive Growth of Kazan Federal University.

\section{REFERENCES}

Karpoyan S.M. Otritsatelnyye modalnyye otsenki v internet-kommentarii / S.M. Karpoyan // Nauchnaya mysl Kavkaza. - Rostov-na-Donu, 2011. №3. p. 115-119. (Negative Assessment in Internet-Commentary Scientific Thought of Caucasus)

Karpoyan S.M. Epistemicheskiye rechevyye akty v internet-kommentarii / S.M. Karpoyan // Vestnik Moskovskogo gosudarstvennogo oblastnogo universiteta. Seriya: Lingvistika. - Moskva, 2011. - № 5. p. 38 -43 .

Koshel' P.V. Frantsuzskiy internet-kommentariy kak rechevoy zhanr / P.V. Koshel' // Vestnik Moskovskogo gosudarstvennogo lingvisticheskogo universiteta. Moskva, 2013. - № 10 (670). p. 80 - 89.

Savel'yeva I.V. K voprosu o zhanrovykh priznakakh internet-kommentariya / I.V. Savel'yeva // Zhanry i tipy teksta $\mathrm{v}$ nauchnom i mediynom diskurse : mezhvuzovskiy sbornik nauchnykh trudov. Orel, 2013. p. $194-$ 202.

Abdullina, L.R. Ageeva, A.V. Smirnova E.A. The Evolution of the 'Comment' Genre: Theoretical Aspect; (2014) World Applied Sciences Journal, Vol. 29 (3), pp. 354 - 358.

Atifi H., Marcoccia M. Follow-ups and dialogue in online discussions on French politics The Dynamics of Political Discourse: Forms and functions of follow-ups p.109-139

Colin J.-Y., Mourlhon-Dallies F. Du courier des lecteurs aux forums de discussion sur l'internet : retour sur la notion de genre. - Les discours de l'internet: nouveaux corpus, nouveaux modèles? — Les carnets du Cediscor 8 - Presses Sorbonnes Nouvelles. - p.113 - 139.

Doury M., Marcoccia M. Forum internet et courrier des lecteurs : l'expression publique des opinions. Hermès, La Revue 2007/1 ( ${ }^{\circ}$ 47). p. 41-50 
Bets M.V. Vyyavleniye lingvokul'turnykh osobennostey natsional'noy yazykovoy lichnosti na primere internet-kommentariyev k novostyam / M.V. Bets // Mir nauki, kul'tury, obrazovaniya. Gorno-Altaysk, 2013. № 4 (41). p. 55 - 57.

Romantovskiy A.V. Rekonstruktsiya motivatsionnogo urovnya yazykovoy lichnosti $\mathrm{v}$ diskurse internetkommentariyev (na materiale foruma informatsionnogo portala) / A.V. Romantovskiy // Vestnik Irkutskogo gosudarstvennogo tekhnicheskogo universiteta. Irkutsk, 2014. №5(88). p.266 -270.

Abdullina L.R., Ageeva A.V. Natsional'naya spetsifika kommentariya k politicheskoy novosti v virtual'nom frankoyazychnom diskurse / L.R. Abdullina, A.V. Ageeva // Vestnik VGU. Seriya: Filologiya. Zhurnalistika. - Voronezh, 2014. - №2 - p.89-93

Bondarenko Ye.N. Analiz rechevoy strategii diskreditatsii v lingvisticheskoy ekspertize (na primere internetkommentariya) / Ye.N. Bondarenko // Filologicheskiye nauki. Voprosy teorii i praktiki. - Tambov, 2014. № 10-1 (40). - p. 27-29.

Savel'yeva I.V. Tekstovyye strategii pri porozhdenii internet-kommentariyev: lingvopersonologicheskiy aspekt / I.V. Savel'yeva // Mir nauki, kul'tury, obrazovaniya. - Gorno-Altaysk, 2013. - № 4 (41). - p. 50-52.

Steksova T.I. Rechevaya agressiya $\mathrm{v}$ internet-kommentariyakh kak proyavleniye sotsial'noy napryazhennosti / T.I. Steksova // Politicheskaya lingvistika. - Yekaterinburg, 2013. - № 3. - p. 77-81.

Gusel'nikova A. V. Terminologicheskiy apparat struktury freyma / A. V. Gusel'nikova // Vestnik CHGPU. Chelyabinsk, 2010. - № 9. - p. 137-149. 